2nd International Conference Global Ethics -Key of Sustainability (GEKoS) | May 14, 2021 | Bucharest, Romania

\title{
Possibilities for Implementing Anti-Bullying Elements in the e-Learning Process
}

\author{
Iuliana MIHAI (VASILE)
}

https://doi.org/10.18662/lumproc/gekos2021/17

How to cite: Mihai (Vasile), I. (2021). Possibilities for Implementing AntiBullying Elements in the e-Learning Process. In A. Grigorescu \& V. Radu (vol. ed.), Lumen Proceedings: Vol. 15. 2nd International Conference Global Ethics Key of Sustainability (GEKoS) (pp. 199-207). Iasi, Romania: LUMEN Publishing House. https://doi.org/10.18662/lumproc/gekos2021/17 
Iuliana MIHAI (VASILE) | Lumen Proceedings 15 | GEKoS 2021

\title{
Possibilities for Implementing Anti-Bullying Elements in the e-Learning Process
}

\author{
Iuliana MIHAI (VASILE) ${ }^{1}$
}

\begin{abstract}
Bullying is not a new phenomenon, but it has spread in recent years through a new form: cyberbullying, as a result of technological evolution. The negative effects are multiple, from anxiety, bealth problems, to dropping out of school and even suicide. To make the school a safe environment for children, methodological norms have appeared to prevent and combat bullying manifestations in the school environment.

In the context of the Covid-19 pandemic, when many activities continued online, education also acquired a new dimension: e-Learning. Information devices (computers, tablets, smartphones) have taken over the occupations of young people and exposed them to cyber risks, pseudo-socialization, technological dependence. Online safety of students is a necessity and a topical issue, in which the family, the school and the community should be involved, and training through courses is a first step in solving this problem.

This paper briefly presents the dangers caused by the misuse of technology, as well as the entrepreneurial perspective of anti-bullying intervention, through online training courses.
\end{abstract}

Keywords: Bullying, e-learning, entrepreneurship, training courses.

${ }^{1}$ Valahia University of Târgoviste, Romania, yliavasile@yahoo.com 
Iuliana MIHAI (VASILE) | Lumen Proceedings 15 | GEKoS 2021

\section{Introduction in cyber-bullying}

The Screens and digital media are now part of everyday life, from an early age. According to studies (Online Nation 2020 Summary report), shielding can increase the negative impact on children's health and development, related to obesity and reduced physical activity (Ofcom, 2020). In preschool children, it can replace the interaction between parents or supervisors and has been associated with cognitive and socio-emotional retardation (Dudley-Nicholson, 2021). But beyond the danger of shielding appears a phenomenon that causes enormous stress and is extremely harmful to young people - cyberbullying (Purwanto et al., 2020).

The phenomenon of bullying has always been a reality in schools. Initially, the manifestations were direct (face to face), through physical or verbal bullying (pushes, blows, pinches, suffocations, nicknames) and the people involved (aggressor and victim) shared the same physical space, carried out activities together (Neiman et al., 2012). Currently, bullying can be continued in the virtual environment, by using devices connected to the Internet, intimidation and harassment in the intimate space of the home. Technology dependence amplifies this phenomenon; It is a known fact that many young people are still strong in the virtual life of social networks, which are a lifestyle for these individuals (Dubey \& Tripathi, 2020).

Cyberbullying is a new manifestation of bullying that, in recent years, has been recognized as an important educational issue that affects the lives of many students (Kalakuntla et al., 2019). Although there is no unanimously accepted definition, recent studies define cyber-bullying as the use of electronic devices connected to the Internet to send and post embarrassing images, create websites or send inappropriate messages to other people. Unlike common bullying, cyber-bullying is much crueller. The perpetrators can benefit from hiding their identity and intimidation can turn into harassment or terrorization, with tragic consequences for the victim (Hinduja \& Patchin, 2013).

It is known that young people are a group with an increased emotional vulnerability, more sensitive to emotional aggression. Hence, the need for interventions and measures to raise awareness of the impact of this phenomenon on the lives of young people and emotional well-being is one of the main conditions of quality life (Popovici et al., 2020).

An important aspect is the role of the witness of the aggression, who can be a simple spectator, ignoring the aggression, or can be active, instigating the aggressor or trying to stop the bullying. In most cases, when witnesses intervene, bullying stops within 10 seconds (Morgan, 2020). 
Contextually, the pandemic has made people all the more likely to use the services provided over the Internet to communicate with each other - through voice, video, text and e-mail services. Also, the time spent online has increased significantly, many of the activities taking place in the online environment.

\section{E-Learning - a new dimension of education}

A new form of learning has emerged in the school environment: elearning, which aims to facilitate learning and increase performance in education through the use of appropriate technological resources for the education system and seeks to bring together, in the virtual environment, teachers and students, regardless of barriers geographical location and the physical distances between them (Radu et al., 2011). Dobre, I. defines eLearning learning in a virtual world, in which technology cooperates with human creativity to accelerate and facilitate deep knowledge of the field studied (Dobre, 2010, pp. 5-6).

The Covid-19 crisis has affected all sectors of activity, including education. The saving solution was e-Learning. Although the beginning was difficult for both students and teachers, each adapted as best as possible to the context and, in general, the technological limitations were overcomed, using devices connected to the Internet, online resources, educational applications that have facilitated education (Table 1).

Table 1. Advantages and disadvantages of e-learning Source: Dobre (2010, pp. 16-18)

Advantages

- Crossing physical borders;

- The possibility to access educational content at any time and from anywhere;

- Efficient presentation of the information;

- Linking learning styles to the benefit of the students;

- Combining traditional learning methods with modern learning methods;

- Adequacy of time resources according to the needs of the group;

- Creating focused groups

Disadvantages

- Internet access is not available for all children;

- The need for adult supervision;

- Security of personal data;

- Security of personal data;

- Cyber-bullying 
Although some activities were physically resumed (student courses), teacher training and development programs continued to be conducted online.

In Romania, according to Law $1 / 2011$ (Art. 245), continuous training is a right and an obligation for teaching, management, guidance and control staff. Ongoing training of teachers, management, guidance and control and professional retraining is based on quality standards, standards and professional competencies ${ }^{2}$.

By the regulations specific to lifelong learning and adult education, teacher training is through mandatory training courses. The teaching staff, as well as the management, guidance and control staff in pre-university education is obliged to periodically participate in continuous training programs, to accumulate, at each consecutive interval of 5 years, considered from the date of passing the final exam in education, minimum 90 transferable professional credits (Morgan, 2020). Continuing education ensures the updating and development of teachers 'competencies, including the acquisition of new competencies, according to the evolutions in terms of educational needs and the educational curriculum, as well as according to the requirements regarding the adaptation of teachers' competencies to changes in structures/ education processes.

The evaluation and validation of the acquisitions acquired by the teaching staff through different programs and forms of organization of the continuous training/improvement are carried out through the system of recognition, equivalence and accumulation of the transferable professional credits.

The evaluation of continuous training is performed by:

a) accumulation of transferable professional credits;

b) validation of the competencies obtained in the didactic activity included in the annual evaluation sheets of the teaching staff, in the inspection reports and class assistance;

c) portfolio scoring.

The training programs and activities provided above can be organized in flexible forms of education, adapted to the objectives and contents of the training, as well as to the possibilities and requirements of the participants, respectively:

\footnotetext{
${ }^{2}$ Law no. 221 of November 18, 2019 for amending and supplementing the National Education Law no. 1/2011. Issued by the Parliament of Romania. Published in the Official Gazette no. 929 of November 19, 2019
} 
- by frequent courses, organized modularly, during the school holidays, on non-working days or working days allocated especially to the training activities;

- in the distance learning system, by using E-learning platforms and electronic supports, combined with the orientation and assistance of learning through tutoring procedures;

- through non-attendance courses organized by higher education institutions, combined with regular consultations, according to the participants' options;

- through other forms of organization that combine learning assisted by trainers (through courses, seminars, laboratories and joint practical activities), with learning through individual study and independent activity of the participants.

On June 10, 2020, the methodological norms for the application of the law on preventing and combating bullying in schools were published, approved by order of the Minister of Education. According to this document, in each school organization an anti-bullying action group will be set up, which will include a maximum of 10 members, which will have the role of preventing, identifying and solving acts of bullying committed between students, through physical, verbal actions, relational and/or cybernetic.

\section{Aims of the research}

The objective of these methodological norms is to facilitate the creation of a safe and positive climate in the school, based on respect for the person, non-discrimination, motivation for learning and ensuring the wellbeing of the preschooler / schooler/student in the school.

The methodological rules also provide a working tool for professionals working with preschoolers / schoolers / students in the education system, children's families, authorities responsible for protecting children against violence, including psychological violence-bullying, and with providers of specialized services for the rehabilitation of children-victims, witnesses and/or children with aggressive behaviour (Figure 1) 


\section{School}

Family

\section{Cummunity}

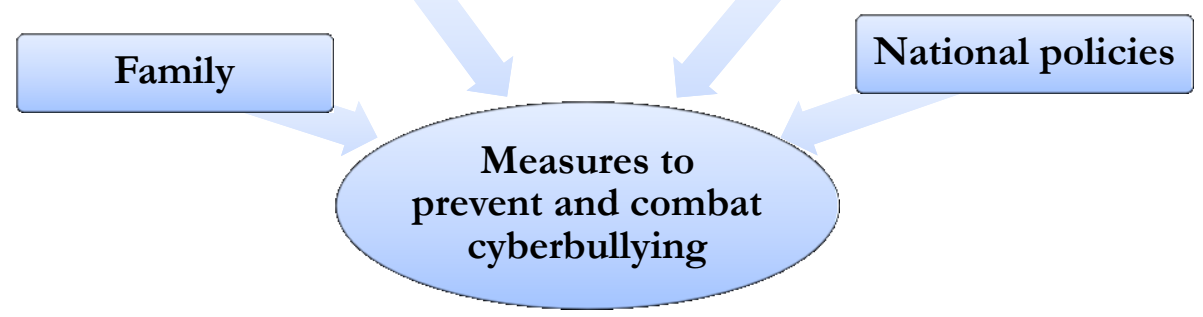

Figure 1. Anti-bullying educational partners

Source: Author interpretation

Starting from one of the priority directions of education, that of reducing violence in the school environment, a training program on preventing and combating the phenomenon of bullying is welcome among teachers. And to adapt to the current context, the online format can be an entrepreneurial initiative with great chances of success. In these times of crisis, the niche of online training can be one of the great opportunities in business ethics (Freeman, 2020).

Paradoxically, we are talking about a "treatment" through the problem itself: an online course on online safety, but the intention is to extend the approach to general bullying.

\section{Results}

In An online training program has many advantages for beneficiaries:

- can be accessed from anywhere, eliminating the costs of transport, time and effort to travel;

- the information can be browsed at your own pace, without imposing a predetermined work schedule;

- a balance is ensured between theoretical information and case studies, with suggestive videos;

- ensuring access to an up-to-date database on the phenomenon of bullying worldwide;

- an anti-bullying community is set up, able to cooperate in other contexts as well;

- the certification is made following the evaluation of the knowledge transfer. 
Anti-bullying education must be strongly supported in school, through a common and continuous effort. The target group of this course could go beyond the teaching staff, mobilizing parents, community representatives, NGOs. The diversity of educational environments has an impact on changing children's behavior according to the ideals of the time. But of all these environments, the family has a decisive role (Hinduja \& Patchin, (2019). following:

The basic recommendations in the case of cyber-bullying are the

- collecting evidence of aggression behavior, through screenshots of online posts or private messages, e-mail and text messages;

- reporting abusive posts on social platforms;

- filing a complaint with the competent authorities (criminal complaint under Article 226 of the New Criminal Code, regarding the violation of privacy).

- children can report any form of bullying to the Child's Phone (116111) for help at any time.

\section{Conclusions}

The role of such a training program is to raise awareness of the negative impact of bullying, to emphasize the importance of friendships and collaboration between young people and social skills that can be acquired from an early age (Călugărescu, 2020) has the role of increasing students' confidence in own strengths and to be more confident in adults, to look at this issue from another perspective, that of a phenomenon that can be combated, spiritual education to the idea of zero tolerance to bullying.

For education staff, and not only, access to web resources increases, the quality of the educational process. The Internet is almost indispensable for both students and teachers. Studies in recent years and OECD analyses at the global level show that the use of ICT in education contributes greatly to improving learning outcomes. It is a requirement of the present times to reconfigure the initial and continuous training of all educators to include learning, teaching, online assessment, along with conventional learning, in a hybrid package.

Beyond entrepreneurship, the topicality and the strong negative emotional impact of the bullying phenomenon determine the need for a training program on this topic, as a product with an increased demand on the market of educational services and the current social reality. 
Iuliana MIHAI (VASILE) | Lumen Proceedings 15 | GEKoS 2021

\section{Acknowledgement:}

This work is supported by project POCU 125040, entitled "Development of the tertiary university education to support the economic growth - PROGRESSIO", co-financed by the European Social Fund under the Human Capital Operational Program 2014-2020

\section{References}

Călugărescu, A. G. (2020). The Importance of Teaching Activity in the Process of Cognitive Processing. Holistica-Journal of Business and Public Administration, 11(1), 146-154. https://doi.org/10.2478/hjbpa-2020-0013

Dobre, I. (2010). Studiu critic al actualelor sisteme de e-learning. Academia Română.

Institutul de cercetări pentru inteligență artificială.

https://www.racai.ro/media/Referatul1-IulianaDobre.pdf

Dubey, A., \& Tripathi, S. (2020). Analysing the Sentiments towards Work-From-

Home Experience during COVID-19 Pandemic. Journal of innovation management, 8(1), 13-19. https://doi.org/10.24840/21830606_008.001_0003

Dudley-Nicholson, J. (cited 2021 May 10). Cyberbullying insurance launches in Australia, offering to bide online abuse and counselling for victims. The Courier-Mail. https://www.couriermail.com.au/technology/cyberbullying-insurancelaunches-in-australia-offering-to-hide-online-abuse-and-counselling-forvictims/news-story/93d94534ecb1b2ebeee0ff3bfbf5be77

Freeman, R. E.(2020). Business Ethics in the Time of Covid-19. In A. Grigorescu\& V. Radu (vol. ed.), Lumen Proceedings: Vol. 11. 1st International Conference Global Ethics -Key of Sustainability (GEKoS) (pp. 1-3). Iasi, Romania: LUMEN Publishing House. https://doi.org/10.18662/lumproc/gekos2020/01

Hinduja, S., \& Patchin, J. W. (2013). Social influences on cyberbullying behaviors among middle and high school students. Journal of youth and adolescence, 42(5), 711-722. https://doi.org/10.1007/s10964-012-9902-4

Hinduja, S., \& Patchin, J. W. (2019). Connecting adolescent suicide to the severity of bullying and cyberbullying. Journal of school violence, 18(3), 333-346. https://doi.org/10.1080/15388220.2018.1492417

Kalakuntla, R., Vanamala, A. B., \& Kolipyaka R. R. (2019). Cyber Security. HOLISTICA-Journal of Business and Public Administration, 10(2), 115-128. https://doi.org/10.2478/hjbpa-2019-0020 
Iuliana MIHAI (VASILE) | Lumen Proceedings 15 | GEKoS 2021

Morgan, H. (2020). Best practices for implementing remote learning during a pandemic. The Clearing House: A Journal of Educational Strategies, Issues and Ideas, 93(3), 135-141. https://doi.org/10.1080/00098655.2020.1751480

Neiman, S., Robers, B., \& Robers, S. (2012). Bullying: A state of affairs. The Journal of Law of Education, 41,603.

https://heinonline.org/HOL/LandingPage?handle=hein.journals/jle41\&di $\mathrm{v}=38$ \&id $=$ \&page $=$

Ofcom. (2020). Online Nation 2020 Summary report.

https://www.ofcom.org.uk/_data/assets/pdf_file/0027/196407/onlinenation-2020-report.pdf

Popovici, N., Munteanu-Florea, I., \& Condrea, E. (2020). A Perspective on Quality of Life. In A. Grigorescu \& V. Radu (vol. ed.), Lumen Proceedings: Vol. 11. 1st International Conference Global Ethics -Key of Sustainability (GEKoS)(pp. 4555). Iasi, Romania: LUMEN Publishing House. https://doi.org/10.18662/lumproc/gekos2020/06

Purwanto, A., Asbari, M., Fahlevi, M., Mufid, A., Agistiawati, E., Cahyono, Y., \& Suryani, P. (2020). Impact of Work From Home (WFH) on Indonesian Teachers Performance During the Covid-19 Pandemic: An Exploratory Study. International Journal of Advanced Science and Technology, 29(5), 6235-44. http://sersc.org/journals/index.php/IJAST/article/view/15627

Radu, F. L., Radu, V. A., \& Croitoru , G. (2011). The advantage of the new technologies in learning. In 10 th international conference on Artificial intelligence, Knowledge Engineering and Data Bases (pp. 150-155). http://www.wseas.us/elibrary/conferences/2011/Cambridge/AIKED/AIKED-25.pdf 